
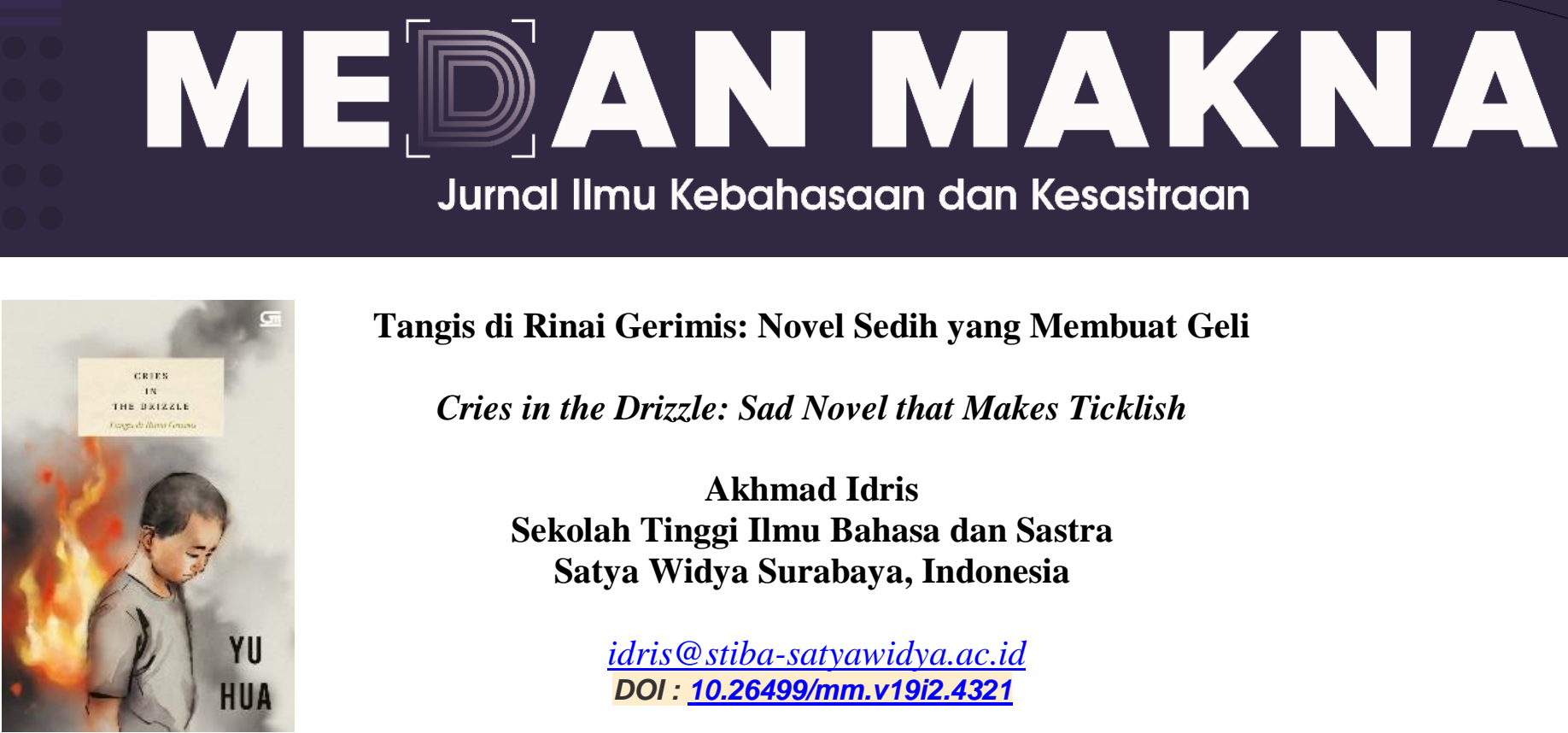

Tangis di Rinai Gerimis: Novel Sedih yang Membuat Geli

Cries in the Drizzle: Sad Novel that Makes Ticklish

\author{
Akhmad Idris \\ Sekolah Tinggi Ilmu Bahasa dan Sastra \\ Satya Widya Surabaya, Indonesia
}

idris@stiba-satyawidya.ac.id

DOI : 10.26499/mm.v19i2.4321

\title{
Identitas Buku
}

Judul

: Tangis di Rinai Gerimis (Terjemahan dari Cries in the

Drizzle yang juga terjemahan dari naskah asli Zai Xiyu

Zhong Hunan)

Penulis

: Yu Hua

Penerjemah

: Berliani M. Nugrahani

Penerbit

: Gramedia Pustaka Utama

Cetakan

: Februari 2021

Tebal

: 312 halaman

ISBN

: 978-602-06-4826-2

Kali pertama melihat judul; tentang penderitaan yang tak terbantahkan. ilustrasi di kover depan; dan rangkuman Ditambah lagi ringkasan singkat yang singkat di kover belakang, semuanya tampak jelas bahwa novel ini hendak menuturkan kisah menyedihkan tentang bocah lelaki yang bernama Sun Guanglin. Judul tangis di rinai gerimis yang dipadukan dengan ilustrasi bocah lelaki yang tertunduk sedih, memunggungi kobaran api seolah memancing interpretasi menyebutkan bahwa ada bocah kecil yang diabaikan oleh keluarganya hingga berstatus sebagai anak terbuang, kian mengukuhkan dugaan kandungan sendu dan haru di dalamnya. Namun setelah menuntaskan pembacaan hingga bagian paling ujung, Tangis di Rinai Gerimis adalah novel sedih yang membuat geli. 


\section{Bermain Satire saat Adegan Sedih}

Lewat Tangis di Rinai Gerimis, Yu Hua berhasil menampilkan potret kemiskinan masyarakat pedesaan Zhejiang pada tahun 1960 sampai 1970-an lewat kepolosan Sun Guanglin sebagai tokoh utama dengan menggunakan sudut pandang orang pertama. Allan H. Barr selaku penerjemah ke versi bahasa Inggrisnya bahkan dengan gamblang menyebutkan bahwa cerita di dalam novel Tangis di Rinai Gerimis adalah karya yang paling merefleksikan pengalaman Yu Hua sendiri daripada karya-karya Yu Hua lainnya. Di antara potret kemiskinan wilayah pedesaan Zhejiang dalam novel ini adalah ketimpangan sosial antara anakanak desa dan anak-anak kota. Anak-anak desa yang diwakili oleh Sun Guanglin, Kakaknya, dan adiknya digambarkan sebagai bocah-bocah bertelanjang dada serta berkulit gelap sebab paparan sinar matahari (halaman 11). Sementara anakanak kota ditampilkan dengan pakaian sempurna yang duduk nikmat menghadap mangkuk dan sumpit (halaman 12).

Meskipun tampak menyedihkan, $\mathrm{Yu}$ Hua justru menceritakannya dengan menyenangkan karena gaya satire yang digunakannya. Sebagaimana yang disampaikan oleh Gorys Keraf (2010) dalam Diksi dan Gaya Bahasa bahwa satire digunakan untuk mengungkapkan kekurangan manusia yang ujung-ujungnya membuat tertawa. Hal yang membuat satire bisa mengundang tawa menurut Suminar (2017) adalah gaya cemoohan yang diungkapkan dengan mendistorsi fakta sebagai cara untuk mengkritik secara tidak langsung. Di tengah ketimpangan sosial tersebut, Yu Hua membuat ungkapan satire dari ucapan Sun Guangping_-kakak Sun Guanglin-yang berhasil menjungkirbalikkan ketimpangan tersebut dengan kalimat berikut,

"Kita berharap bisa menjadi orang kota, tapi orang kota cuma ingin menjadi badut." (halaman 20)

Setidaknya nasib kurang beruntung yang dimiliki orang desa membuat mereka tetap menjadi manusia normal yang ingin berusaha. Tidak seperti orang kota yang justru berbahagia menjadi badut karena sibuk bersenang-senang daripada berpikir matang. Kurang lebih seperti itu maksud ungkapan Sun Guangping.

\section{Penggunaan Estetika Pertentangan}

Selain satire, Yu Hua juga menampilkan pertentangan antara yang diceritakan dan yang dipahami orang kebanyakan. Kontradiksi inilah yang memunculkan estetika dalam sastra, yang oleh Djoko Saryono (2006) dalam Pergumulan Estetika Sastra di Indonesia disebut dengan istilah estetika pertentangan. Hal ini dapat dilihat saat Sun Guanglin menganggap kematian orang asing sebagai hal yang menakjubkan, bukan hal yang membuat kekalutan sebagaimana dalam kutipan berikut ini,

"Bagiku yang baru enam tahun, kematian mendadak seorang asing hanya memicu ketakjuban, tidak menyebabkan kekalutan. Orang itu telentang di tanah lembab, matanya terpejam, raut mukanya tenang dan damai." (halaman 9)

Berbeda dengan pandangan kebanyakan orang yang justru diserbu panik kala mengetahui kematian orang tak dikenal, Yu Hua justru menampilkan sudut pandang yang bertentangan dengan makna umum bahwa kematian adalah hal yang bisa membuat orang takjub lewat sikapnya yang tiba-tiba telentang; matanya terpejam; 
hingga pesona wajah yang tenang. Tak salah jika Yu Hua menyebut mati itu tak perlu membuat orang kebingungan, sebab orang yang mati itu seperti orang yang sedang tidur.

Estetika pertentangan yang lain dihadirkan oleh Yu Hua lewat potret kengerian masyarakat pada masa desingan peluru antara tentara Nasionalis dan Komunis. Sebuah era yang menyisakan orang-orang telantar dan orang-orang yang kelaparan. Yu Hua menyebutnya dengan istilah kontradiktif yang berupa pembinasaan-pembangunan yang dapat dilihat pada kutipan berikut ini,

"Kakekku masih berambisi membangun jembatan, tetapi dia hidup di zaman yang salah, di era yang lebih mengedepankan pembinasaan daripada pembangunan." (halaman 162-163)

Berbeda dengan tujuan sebuah pemerintahan yang seyogianya melakukan pembangunan untuk kesejahteraan rakyatnya, namun Yu Hua membeberkan fakta yang sebaliknya bahwa pada masa itu pemerintahan hanya sibuk melakukan pembinasaan daripada pembangunan. Oleh sebab itu, setiap orang pada masa itu hidup seperti seorang buruan. Yang hanya berusaha mencari pekerjaan demi tetap melanjutkan kehidupan malah disangka seorang gerilyawan komunis yang harus dikejar dengan rentetan tembakan.

Selain pertentangan tentang kematian dan sistem pemerintahan, $\mathrm{Yu}$ Hua juga menampilkan estetika pertentangan lewat kejadian konyol selama tragedi pengejaran oleh pasukan Nasionalis tersebut. Kejadian konyol itu bermula saat tokoh Sun Youyuan sedang tertidur di pinggir sungai karena lelah berlari, tibatiba terbangun karena rentetan suara tembakan sebagaimana kutipan berikut,

"Saat rentetan tembakan pertama terdengar, Sun Youyuan sontak terbangun dan berseru, 'Apa-apaan ini, siapa yang bermain petasan?"' (halaman 163)

Dengan jenakanya, Yu Hua menyisipkan dialog Sun Youyuan yang menyebut tembakan dengan orang yang bermain petasan. Tampak jelas bahwa ini adalah kondisi yang sangat bertentangan, sebab rentetan tembakan bermakna upaya pembunuhan, sedangkan suara petasan merupakan bentuk permainan untuk kesenangan.

Akhir kata, setiap sastra memang memiliki caranya sendiri untuk menyampaikan hal-hal yang tersembunyi. Seperti Yu Hua yang menyampaikan kesedihan dengan gaya bahasa yang menggelikan.

\section{DAFTAR PUSTAKA}

Keraf, Gorys. (2010). Diksi dan Gaya

Bahasa. Jakarta: PT Gramedia Pustaka Utama.

Saryono, Djoko. (2006). Pergumulan Estetika Sastra di Indonesia. Malang: Pustaka Kayutangan.

Suminar, Agustina. (2017). Wacana Satire Politik dalam Situs Mojok.co. Universitas Airlangga: Skripsi. Diakses secara daring di https://repository.unair.ac.id/67890 I 